\title{
Suppression of miR-155 attenuates lung cytokine storm induced by SARS- CoV-2 infection in human ACE2-transgenic mice
}

\section{Dharmendra Kumar Soni ${ }^{1}$, Juan Cabrera-Luque ${ }^{2}$, Swagata Kar ${ }^{3}$, Chaitali Sen ${ }^{1}$, Joseph}

\section{Devaney $^{2}$, and Roopa Biswas ${ }^{1}$}

${ }^{\mathbf{1}}$ Department of Anatomy, Physiology and Genetics, Uniformed Services University School of Medicine, Uniformed Services University of the Health Sciences, Bethesda, MD, 20814.

$$
{ }^{2} \text { GeneDx, } 207 \text { Perry Pkwy, Gaithersburg, MD } 20877 .
$$

${ }^{3}$ Bioqual Inc., 9600 Medical Center Drive, Suite 101, Rockville, MD 20825.

\section{Short title: Anti-miR-155 therapy for COVID-19}

\footnotetext{
*Address correspondence requests to Roopa Biswas, Department of Anatomy, Physiology and Genetics, Room B4024, Uniformed Services University of the Health Sciences, 4301 Jones Bridge Road, Bethesda, Maryland 20814. E-mail address: roopa.biswas@ usuhs.edu
} 


\section{ABSTRACT}

Coronavirus disease 2019 (COVID-19) is a recent global pandemic. It is a deadly human viral disease, caused by the severe acute respiratory syndrome coronavirus 2 (SARS-CoV-2), with a high rate of infection, morbidity and mortality. Therefore, there is a great urgency to develop new therapies to control, treat and prevent this disease. Endogenous microRNAs (miRNAs, miRs) of the viral host are key molecules in preventing viral entry and replication, and building an antiviral cellular defense. Here, we have analyzed the role of miR-155, one of the most powerful drivers of host antiviral responses including immune and inflammatory responses, in the pathogenicity of SARS-CoV-2 infection. Subsequently, we have analyzed the potency of anti-miR-155 therapy in a COVID-19 mouse model (mice transgenic for human angiotensin Iconverting enzyme 2 receptor (tg-mice hACE2)). We report for the first time that miR-155 expression is elevated in COVID-19 patients. Further, our data indicate that the viral load as well as miR-155 levels are higher in male relative to female patients. Moreover, we find that the delivery of anti-miR-155 to SARS-CoV-2-infected tg-mice hACE2 effectively suppresses miR-155 expression, and leads to improved survival and clinical scores. Importantly, anti-miR155-treated tg-mice hACE2 infected with SARS-CoV-2 not only exhibit reduced levels of proinflammatory cytokines, but also have increased anti-viral and anti-inflammatory cytokine responses in the lungs. Thus, our study suggests anti-miR-155 as a novel therapy for mitigating the lung cytokine storm induced by SARS-CoV-2 infection.

Keywords: Coronavirus disease 2019 (COVID-19); Severe acute respiratory syndrome coronavirus 2 (SARS-CoV-2); MicroRNA-155, Anti-miR-155, Cytokine storm, Lung inflammation 


\section{INTRODUCTION}

Coronavirus disease 2019 (COVID-19) is a life-threatening human viral disease, caused by the severe acute respiratory syndrome coronavirus 2 (SARS-CoV-2) and accountable for the high rate of infection, hospitalization, morbidity and mortality around the world. The outbreak of this deadly human viral pathogen was first reported in December 2019 in Wuhan city of China $(1,2)$. Subsequently, due to its exceedingly high rate of human-to-human transmission and infection, SARS-CoV-2 rapidly transmitted throughout the world with a very high prevalence, leading to a global pandemic. As of December 8, 2020, almost all (177) countries/regions have reported more than $67,781,393$ cases of patients infected with SARS-CoV-2, and 1,548,516 deaths, worldwide, and this continues to rise at an exponential rate (https://coronavirus.jhu.edu/map.html) (3). Therefore, there is great urgency to curb the spread of SARS-CoV-2 and treat infected patients, by developing new therapies to control, treat and prevent this disease. To date, a diverse array of therapeutics COVID-19 is in phase three clinical trial to, such as two mRNA-based vaccine candidate, mRNA-1273 (NIAID and Moderna, Inc.) and BNT162b2 (Pfizer and BioNTech), and a vaccine developed against the SARS-CoV-2 virus spike protein, AZD1222 (University of Oxford and AstraZeneca). Despite the rapid pace with which researchers and manufacturers are moving potential therapeutics into clinical trials, developing effective countermeasures against COVID-19 remains an unmet goal.

The upper respiratory tract is the main site for active replication of SARS-CoV-2, and the severity of the disease depends upon the expression of the viral receptor by lung epithelial cells (4-6). Further, increased inflammatory responses and cytokine storm (such as interleukin (IL)-1 $\beta$ IL-2, IL-6, IL-7, IL-8, tumor necrosis factor- $\alpha$ (TNF- $\alpha$ ), granulocyte-colony stimulating factor (G-CSF) and granulocyte-macrophage colony-stimulating factor (GMCSF)) have been reported in the lungs of severe COVID-19 patients (7-9). In addition, elevated 
expression of numerous chemokines (monocyte chemoattractant protein 1 (MCP1), interferon$\gamma$ inducible protein 10 (IP10) and macrophage inflammatory protein 1- $\alpha$ (MIP1- $\alpha)$ ) have also been reported in COVID-19 patients $(7,9,10)$. These investigations clearly indicate that the expression of viral specific-receptor by lung epithelial cells have a key role in the entry of SARS-CoV-2 and during infection, immune responses have a critical function in the regulation of inflammation. Therefore, preventing virus entry or replication and/or reinstating or modulating host immunity responses can open a new avenue to control, treat and prevent COVID-19.

Recently, microRNAs (miRNAs, miRs), short ( 22 nucleotides) endogenous noncoding RNAs, have emerged as prominent regulators of human defense mechanisms in airway inflammation, lung diseases as well as in various acute respiratory distress syndromes (ARDS). Importantly, in viral infection and disease, the host's endogenous miRNAs have a decisive function in preventing viral entry and replication either by direct degradation of viral RNA or suppression of translation of proteins involved in replication $(11,12)$. Furthermore, miRNAs play a predominant role in building antiviral cellular defense and are critical regulators of host immunity and inflammatory responses by inducing mRNA degradation and/or repressing mRNA translation of target genes $(13,14)$. Over $60 \%$ of human genes are targets of miRNAs and are regulated by miRNAs $(15,16)$. Altered expression of specific miRNAs have been demonstrated in a variety of human diseases including cancer, heart disease, immunological disorders, and diabetes (17-22). Notably, studies have illustrated the association of several miRNAs with immune response against various respiratory viruses such as influenza virus (IV), respiratory syncytial virus (RSV), human rhinovirus (hRV), human metapneumovirus (hMPV), and human coronavirus (HcoV) $(12,23,24)$. Some miRNAs regulate levels of immunomodulating factors and suppress or promote inflammatory responses (25). Moreover, since a single miRNA targets multiple genes and modulates the expression of these genes, the 
best way to nullify the consequence of a dysregulated miRNA in diseased cells, is to restore or inhibit expression (26). Single miRNAs have been shown to stimulate therapeutic responses in animal disease models as well as in human clinical trials (26-29). Therefore, miRNA replacement or inhibitor-based therapeutic mechanisms can be exploited to prevent viral entry or replication and/or restore or modulate host immune responses against COVID-19.

MiR-155, a well-studied miRNA, is one of the most powerful regulators of host antiviral responses including immune and inflammatory responses (30-33). In recent years, numerous studies have clearly established that miR-155 is evolutionarily conserved and during viral infections, its expression is consistently elevated in different cell systems in both human and animal models (34-39). Furthermore, the role of elevated miR-155 is also correlated with lung inflammation, severity of disease and higher mortality in animal models of ARDS (4043). Interestingly, suppression of miR-155 reduces lung inflammation and induce more rapid recovery of mice infected with respiratory viral pathogens $(42,43)$. Likewise, knock out $(\mathrm{KO})$ of miR-155 or treatment with anti-miR-155 suppresses cigarette smoke-induced lung inflammation in mice models (44). These studies emphasize the role of miR-155 in the modulation of host defense responses during respiratory virus infection.

Here, we have analyzed the viral load of SARS-CoV-2 and expression level of miR155 in nasopharyngeal samples of COVID-19 patients. Further, we have evaluated the effect of anti-miR-155 treatment on SARS-CoV-2-infected COVID-19 mouse model, mice transgenic for human angiotensin I- converting enzyme 2 receptor (tg-mice hACE2, tg-mice). Our data indicate that miR-155 expression is significantly elevated in COVID-19 patients. Interestingly, a relatively higher SARS-CoV-2 viral load and miR-155 expression are observed in male COVID-19 patients compared to female patients. Further, our data demonstrate that treatment of SARS-CoV-2-infected tg-mice with anti-miR-155 is effective in suppression of miR-155 expression in the lung tissues, and also promotes improved survival as well as a slight 
increase in body weight. Moreover, anti-miR-155-treated tg-mice have reduced expression of pro-inflammatory cytokines as well as increased anti-viral and anti-inflammatory cytokines responses in the lungs. These data collectively suggest anti-miR-155 as a novel therapy for mitigating the lung cytokine storm induced by SARS-CoV-2 infection.

\section{RESULTS}

\section{Higher viral load in SARS-CoV-2 positive male patients}

In order to determine the SARS-CoV-2 viral load in COVID-19 patients, a total of 99 human subjects were examined using nasopharyngeal swabs. The isolated RNA was analyzed using COVID-19 RT-PCR diagnostic kit with probes specific for SARS-CoV-2 genes encoded by the RNA-dependent RNA polymerase (RdRp/ORF1ab), Nucleocapsid (N) and Spike (S) protein. Expression of MS2 phage was used as an internal control. From a total of 99 human subjects, 59 (21 male and 38 female; median age, 33 years; range, 12 to 70) tested positive for SARS-CoV-2 infection and 40 (18 male and 22 female; median age, 30 years; range, 13 to 84 ) tested negative for SARS-CoV-2 infection. Our data indicate that the mean $\mathrm{Ct} \pm \mathrm{SEM}$ value for ORF1ab, N and S gene were 21.83 $\pm 0.84,23.84 \pm 0.84$ and 21.36 \pm 0.90 , respectively, in COVID19 positive patients (Fig. 1A). Further, in the gender-wise grouping analyses, lower Ct values of SARS-CoV-2 genes was observed in male $(n=21)$ relative to female $(n=38)$ patients $($ Fig. 1B), indicating that SARS-CoV-2 viral load is higher in male compared to female COVID-19 patients. However, we acknowledge that larger sample size is required to establish these observations.

\section{Elevated miR-155 expression in SARS-CoV-2 positive patients}

We analyzed the expression level of miR-155 in the RNA isolated from nasopharyngeal swabs of 99 human subjects (59 positive and 40 negative for SARS-CoV-2 infection) examined for SARS-CoV-2. We find that miR-155 is significantly elevated in patients who tested positive 
relative to those who tested negative for SARS-CoV-2 infection. Additionally, 34\% $(n=20)$ of the patients positive for SARS-CoV-2 infection showed $\geq 2$-fold upregulation of miR-155 relative to those who tested negative for SARS-CoV-2 infection (Figs. 2A and 2B). Further, in the gender-wise grouping analyses, the level of miR-155 expression is higher in male $(n=21$, positive versus $\mathrm{n}=18$ negative for SARS-CoV-2 infection) relative to female $(\mathrm{n}=38$, positive versus $\mathrm{n}=22$, negative for SARS-CoV-2 infection) patients (Fig. 2C). These results indicate that miR-155 is a potential target for COVID-19 therapy.

\section{Delivery of anti-miR-155 suppressed miR-155 expression in lung tissues of SARS-CoV-2- infected tg-mice hACE2}

We evaluated the efficacy of in vivo delivery of anti-miR-155 to the lungs of SARS-CoV-2infected tg-mice hACE2 (strain 034860 B6.Cg-TG (K18-ACE2)2Prlmn/J), obtained from Jackson Laboratory (Bar Harbor, ME, USA). Tg-mice hACE2 (8-10-week-old) were infected via intranasal injection with $2.8 \times 10^{3}$ plaque-forming units (pfu) of SARS-CoV-2 strain USAWA1/2020 (BEI Resources NR-52281, batch \#70033175). Subsequently, the tg-mice were treated with anti-miR-155 or anti-miR-control (scrambled control) via retro-orbital injection at a dose of $25 \mathrm{mg} / \mathrm{kg}$ body weight (BW) in $50 \mu \mathrm{L}$ PBS on 0- and 4-days post-infection (dpi). Total RNA was isolated from the lungs of tg-mice and the expression of miR-155 was measured using miR-155-specifc Taqman assay. As depicted in Fig. 3A, a significant suppression of miR-155 ( $30 \%)$ is observed in the lung tissues of SARS-CoV-2-infected antimiR-155-treated tg-mice $(n=6)$ compared to anti-miR-control tg-mice $(n=3)$. These results demonstrate the effectiveness of anti-miR-155, administered via retro-orbital injection, in suppressing miR-155 in the lung tissues of SARS-CoV-2-infected tg-mice. The dose and administration regime will have to be further optimized. 


\section{Improved survival and body weight of SARS-CoV-2-infected tg-mice after treatment with anti-miR-155}

We examined the effect of anti-miR-155 treatment on BW and survival of tg-mice hACE2 infected with SARS-CoV-2. The anti-miR-155-treated infected tg-mice $(n=6)$ had relatively higher survival compared to the anti-miR-control-treated mice $(n=3)$ (Fig. 3B). All control mice succumbed to infection and were euthanized on $5 \mathrm{dpi}$, while the anti-miR-treated tg-mice survived a day longer and succumbed to infection and were euthanized on 6 dpi. Further, we observed that the anti-miR-155-treated tg-mice showed a slight increase in or stable BW (with a peak during days 2-4), compared to control tg-mice (Fig. 3C). However, subsequently the animals from both anti-miR-155-treated and control group developed clinical signs of disease (weight loss, mild ruffled and hunched back, lethargic, not alert and difficulty breathing). From 4 dpi onwards, SARS-CoV-2-infected anti-miR-155-treated tg-mice as well as control mice displayed a rapid reduction in BW (Fig. 3C). These results emphasize the role of anti-miR155-based therapeutics for COVID-19 and suggests that perhaps a more frequent administration regime, i.e., treatment on alternate days post-infection, could improve the therapeutic efficacy.

\section{Altered levels of inflammatory mediators in the lungs of SARS-CoV-2-infected tg-mice treated with anti-miR-155}

We evaluated the responses of anti-miR-155 treatment on cytokine and chemokine profile in the lungs of SARS-CoV-2-infected tg-mice. Comprehensive analyses of cytokine profile (Luminex, 36-plex MILLIPLEX® MAP Mouse Cytokine/ Chemokine Magnetic Bead kit, EMD Millipore) in the bronchoalveolar lavage (BAL) fluid indicate attenuation of the “cytokine storm" in anti-miR-155-treated tg-mice $(n=5)$ compared to control mice $(n=1)$. We were unable to obtain BAL fluid from one of the treated tg-mice and 2 control tg-mice. The 
data indicate significant downregulation of cytokines and chemokines including G-CSF, IL1 $\alpha$, IL-9, IL-12 (p70), KC, LIX, MIP-2, and VEGF (Fig. 4). Additionally, other cytokines, which are relevant to SARS-CoV-2 infection, such as eotaxin, IFN- $\gamma$, IP-10, MCP-1, M-CSF, MIG, MIP-1 $\alpha$, MIP-1 $\beta$, and TNF- $\alpha$ are induced in anti-miR-155-treated tg-mice compared to control tg-mice (Fig. 5). Importantly, a significant elevation of IFN- $\gamma$, IP-10, and TNF- $\alpha$ suggests the antiviral potency of anti-miR-155 in addition to its anti-inflammatory efficacy in the tg-mice model of COVID-19. These data collectively suggest the anti-inflammatory as well as the anti-viral potency of anti-miR-155 therapy for COVID-19.

\section{DISCUSSION}

From the beginning of this year 2020, the entire world is facing challenges to human health as well as an economic threat because of COVID-19, a deadly human disease caused by a viral pathogen SARS-CoV-2. This had created a global urgency for developing therapeutics against this life-threatening pathogen to control, treat and prevent COVID-19. Currently, many therapeutics strategies are in phase three clinical trials, such as mRNA-1273, BNT162b2, and AZD1222. Despite these recent advances, developing effective countermeasures against this lethal pathogen remains an unmet goal.

SARS-CoV-2 infection primarily affects the lungs and exacerbates host immune and inflammatory responses, which is one of predominant cause for increased cellular damage, severity of disease and death $(45,46)$. Several studies have illustrated the potential of miRNAs, including miR-155 in the regulation of antiviral cellular defense mechanisms and mitigation of infections caused by viral pathogens (30-33, 43, 47-53). However, to date there are no reports of the impact of miR-155 on SARS-CoV-2 infections. Here, we investigated the expression of miR-155 in the nasopharyngeal samples of COVID-19 patients. Our data indicate significant upregulation of miR-155 expression in SARS-CoV-2 positive patients compared to those who 
tested negative. Interestingly, we observed higher SARS-CoV-2 viral load and higher upregulation of miR-155 in SARS-CoV-2 positive male relative to the female patients. However, to establish the gender effect observed analyses of a larger number of patients is required. Consistent with our data, miR-155 has been shown to be induced in the SARS-CoV2-infected Calu-3 lung cell line (54). Another report indicates that only two miRNAs, including miR-155-3p and miR-139-5p, are upregulated in lung epithelial cells upon SARS-CoV-2infection with a significant prediction score (55). Furthermore, recent studies have clearly established that miR-155 is evolutionarily-conserved and during viral infections, its expression is consistently elevated in animal and human models (34-39). Our findings, significantly elevated expression of miR-155 in COVID-19 patients, strongly suggest the regulatory role of miR-155 during SARS-CoV-2 infection.

Interestingly, the elevated expression of miR-155 has been correlated with the severity of disease in ARDS. To define the role of miR-155 during SARS-CoV-2 pathogenesis, we further evaluated the effect of anti-miR-155 treatment on SARS-CoV-2-infected tg-mice hACE2. The wild-type mice are not suitable animal models for studying SARS-CoV-2 infection or the resulting pathologies because the virus does not bind as effectively to the murine ACE2 protein receptor as to ACE2 receptors in humans and several other species. However, tg-mice hACE2 develops severe disease following infection with betacoronaviruses, including SARS-CoV-2 (56-58). Our data demonstrate significant suppression of miR-155 expression in the lungs of SARS-CoV-2-infected anti-miR-155-treated tg-mice relative to control tg-mice, which establishes the in vivo delivery efficacy as well as the effectiveness of anti-miR-155 treatment (administered via retro-orbital injection). Further, the anti-miR-155-treated tg-mice exhibited a slight increase in or stable BW compare to the control tg-mice. However, subsequently both anti-miR-155-treated and control groups of animals developed clinical signs of disease (weight loss, mild ruffled and hunched back, lethargic, not 
alert and difficulty breathing). From 4 dpi, both SARS-CoV-2-infected anti-miR-155-treated and control tg-mice displayed a rapid reduction in BW. Our findings are consistent with previous studies which have reported low survival and significant weight loss in SARS-CoV2-infected tg-mice $(58,59)$. Additionally, our results demonstrated that SARS-CoV-2-infected anti-miR-155-treated tg-mice showed slightly improved survival compared to control tg-mice. Studies on viral infections associated with ARDS have reported that the elevated expression of miR-155 in whole lung tissue is linked to higher mortality and severity of disease in mice (4043). Furthermore, deletion or suppression of miR-155 has been also correlated with decreased lung inflammation and increased recovery of mice infected with respiratory viral pathogens $(42,43)$. The impact of anti-miR-155 treatment in promoting increased survival and BW of mice suggest a vital role of miR-155 in the pathogenesis of SARS-CoV-2. Further, our data also indicate that perhaps a more frequent administration regime, i.e., treatment on alternate days post-infection, could improve the therapeutic efficacy of anti-miR-155.

The high mortality rate of SARS-CoV-2-infected patients has been associated with aggressive inflammatory responses and exaggerated immune responses termed as a cytokine storm. The cytokine storm is characterized by excessive production of various proinflammatory cytokines and chemokines, such as TNF- $\alpha$, IL-1 $\beta$, IL-2, IL-6, IL-7, IL-8, G-CSF, GM-CSF, MCP1, IP10 and MIP1 $\alpha)(7,9,10,46,60-63)$. The role of miR-155 is wellestablished in the induction of pro-inflammatory cytokines and chemokines during numerous viral diseases including ARDS. Therefore, we hypothesized that suppression of miR-155 expression could attenuate excessive production of pro-inflammatory cytokines and chemokines and thereby, mitigate the lung cytokine storm induced by SARS-CoV-2-infection. With this hypothesis, we further evaluated the responses of anti-miR-155 treatment on cytokine and chemokine expression profile in the lungs of SARS-CoV-2-infected tg-mice. The tg-mice infected with SARS-CoV-2 exhibits increased pro-inflammatory responses as observed in 
COVID-19 patients $(57,58)$. The tg-mice infected with SARS-CoV-2 has increased serum protein levels of TNF- $\alpha$, IL-6, and IL-10 as well as the MCP-1 (CCL2) and MCP-3 (CCL7) in the lung homogenates (57). Additionally, the SARS-CoV-2-infected tg-mice also have increased protein levels of interferon- $\beta$ (IFN- $\beta$ ), IFN- $\gamma$, IL-2, IL-6, IL-10, C-X-C motif chemokine ligand 1 (CXCL1), CXCL9, CXCL10, chemokine ligand 2 (CCL2), CCL3, CCL4, CCL5, CCL12, tissue inhibitor of metalloproteinase 1, TNF- $\alpha$ and G-CSF in the lungs (58). Our data indicate that in SARS-CoV-2-infected anti-miR-155-treated tg-mice, BALF inflammatory mediator (cytokines and chemokines) levels are altered with the decrease in GCSF, IL-1 $\alpha$, IL-9, IL-12 (p70), KC, LIX, MIP-2, and VEGF and increase in eotaxin, IFN- $\gamma$, IP-10, MCP-1, M-CSF, MIG, MIP-1 $\alpha$, MIP-1 $\beta$, and TNF- $\alpha$. Importantly, we observed a significant elevation of IFN- $\gamma$, IP-10, and TNF- $\alpha$, suggesting the antiviral potency of anti-miR155 in addition to its anti-inflammatory efficacy in the tg-mice model of COVID-19. Previously, Golden et al. also reported the decreased expressions of Type I and type II IFN transcripts IFNA1, IFNB1, and IFNG, along with the cytokines IL-9 and IL-2 in the lung homogenates of tg-mice upon SARS-CoV-2 infection (57). Similarly, Winkler et al. also reported the variation in the expressions of various cytokines and chemokines in the lungs of SARS-CoV-2-infected tg-mice, while some are increased, some showed no change, and others rapidly increased or decreased following infection (58).

\section{CONCLUSION}

MiR-155 is elevated in the nasopharyngeal samples of COVID-19 patients. The in vivo suppression of miR-155 in SARS-CoV-2-infected tg-mice hACE2 promotes improved survival and can mitigate the cytokine storm and lung inflammation. Thus, our study suggests antimiR-155 as a novel therapeutic candidate for COVID-19. 


\section{METHODS}

\section{Detection of SARS-CoV-2 and measurement of viral load in human patients}

Ninety-nine human subjects (39 male and 60 female; median age, 32 years; range, 12 to 84 ), who were examined for SARS-CoV-2 infection at OPKO Health Company (GeneDx, Inc., MD, USA) were included in this study. Nasopharyngeal swab samples were collected in $3 \mathrm{~mL}$ of standard viral transportation media (VTM). Tubes containing the swab and VTM were pulse-vortexed three times and $1.5 \mathrm{~mL}$ aliquots were collected onto low protein binding tubes (ThermoFisher cat\# 88379). Tubes were then centrifuged at $4^{0} \mathrm{C}$ for 10 minutes at $1500 \mathrm{~g}$. VTM was carefully removed from the tubes and RNA was extracted from pelleted cells. The detection and measurement of SARS-CoV-2 viral load were performed using COVID-19 RTPCR diagnostic kit with specific Taqman probes (ThermoFisher) of SARS-CoV-2-specific genes encoded by the RNA-dependent RNA polymerase (RdRp/ORF1ab), Nucleocapsid (N) and spike (S) protein. MS2 phage was used as an internal control. The expression of the SARSCoV-2 genes was analyzed by the corresponding $\mathrm{Ct}$ values, which are inversely proportional to the viral load.

\section{Measurement of miR-155 expression in human patients}

For analyses of miRNA expression, the RNA was extracted from the VTM using the RNAqueous Micro Kit (ThermoFisher), following manufacturer specifications. During RNA isolation, 100fmol of cel-miR-39 RNA (Ambion) was added as spike-in-control. The expression of miR-155 and cel-miR-39 were analyzed by specific Taqman assays (ThermoFisher). Cel-miR-39 was used as an endogenous control to normalize expression. The relative fold changes of miR-155 were analyzed using the $2^{-\Delta \Delta C T}$ method. 


\section{Mouse model}

Eight to ten weeks old mice transgenic for human angiotensin I- converting enzyme 2 receptor (tg-mice hACE2, tg-mice; average weight $=22$ gm) strain 034860 B6.Cg-TG(K18ACE2)2Prlmn/J were obtained from Jackson Laboratory (Bar Harbor, ME, USA). Animals were housed in groups of five animals per cage and fed standard chow diets. All the experiments with live virus challenge were carried out at BIOQUAL Inc. (Rockville, MD, USA) bio-safety level 3 (BSL-3) facilities in compliance with local, state, and federal regulations under IACUC protocol \#20-083.

\section{Virus challenge}

SARS-CoV-2 strain USA-WA1/2020 (BEI Resources NR-52281, batch \#70033175), courtesy of the Centers for Diseases Control and Prevention (CDC), was used for mice infection. The SARS-COV-2 stock was expanded in Vero E6 cells, and the challenging virus was collected at day 5 of culture when the infection reached $90 \%$ cytopathic effect. The full viral genome sequence showed $100 \%$ identity with the parent virus sequence listed in GenBank (MN985325.1). A plaque-forming assay was carried out in confluent layers of Vero E6 cells and used to determine the concentration of live virions, reported as plaque-forming units (pfu). Virus challenge was performed in tg-mice hACE2 via intranasal injection with $2.8 \times 10^{3} \mathrm{pfu}$ of SARS-CoV-2. Intranasal administration was performed by anesthetizing the animal with Ketamine/ Xylazine. Animals are returned to their housing unit and monitored until fully recovered from the procedure. Bodyweight and clinical observations were monitored daily during the experimental period.

\section{Administration regime for anti-miR-155}

SARS-CoV-2-infected tg -mice hACE2 were treated with anti-miR-155 at a dose of $25 \mathrm{mg} / \mathrm{kg}$ (for an average weight of $22 \mathrm{~g}$ per mouse) in $50 \mu \mathrm{L}$ PBS at 0 - and 4- days post-infection (dpi) 
via Retro-Orbital (RO) injections. A set of control infected tg-mice $(n=3)$ were treated similarly with anti-miR (scrambled)-control. Following the infection of tg-mice with SARS-CoV-2, the lungs from the set of control tg-mice treated with anti-miR (scrambled)-control were isolated on $5 \mathrm{dpi}$, and the lungs from the anti-miR-155-treated tg-mice were isolated on $6 \mathrm{dpi}$. All isolated lungs from control and treated tg-mice were immediately snap-frozen over dry ice and stored at $-80^{\circ} \mathrm{C}$.

\section{Measurement of miR-155 expression in animals}

The total RNA was isolated from frozen lung tissues using TriZol reagent (Invitrogen Inc., Carlsbad, CA) with a mirVana ${ }^{\mathrm{TM}}$ miRNA isolation kit (Ambion, AM1561) and quantitated using Nanodrop (Thermo Scientific). MiRNAs analysis was performed with specific Taqman probes and U6 was used as an endogenous control to normalize expression of miR-155. The relative fold changes of miR-155 were analyzed using the $2^{-\Delta \Delta C T}$ method.

\section{Measurement of cytokine and chemokines}

The level of cytokine and chemokines protein in BAL samples from anti-miR-155-treated tgmice hACE2 and anti-miR (scrambled)-control tg-mice hACE2 were analyzed by Luminex multiplex assays using 36-plex MILLIPLEX® MAP Mouse Cytokine / Chemokine Magnetic Bead kit, (EMD Millipore) according to the manufacturer's protocol.

\section{Statistical analysis}

Statistical analysis for viral load and miR-155 expression was performed using Excel. The data represents average $\mathrm{Ct}$ values or fold changes with the standard error of the mean (mean \pm SEM). The percent change in body weight, Kaplan-Meier survival analyses and alteration in cytokine expression in the experimental compared to control mice were analyzed with Prism version 8 (GraphPad). 


\section{FOOTNOTES}

Disclaimer: The views expressed are those of the authors and do not reflect the official policy or position of the Uniformed Services University of the Health Sciences, the Department of the Defense, or the United States government.

Abbreviations used: COVID-19, coronavirus disease-19; SARS-CoV-2, severe acute respiratory syndrome coronavirus 2; hACE2, human angiotensin I-converting enzyme 2 receptor; miRNA, miR, microRNA; BAL, bronchoalveolar lavage.

\section{Acknowledgements}

The authors thank Samarjit Das (Johns Hopkins University) for helpful discussions, Maciel Porto (Bioqual Inc.) for monitoring the animal study and performing Luminex assays, and Melissa Hamilton (Bioqual Inc.) for processing and analyses of data.

\section{Funds}

This study was supported by NHLBI/USUHS-CHIRP funds 1I80VP000012 and USUHS Intramural Grant $[R B]$.

\section{Conflict of Interest}

There are no competing financial interests in relation to the work described. 


\section{REFERENCES}

1. Guan WJ, Ni ZY, Hu Y, Liang WH, Ou CQ, He JX, Liu L, Shan H, Lei CL, Hui DSC, Du B, Li LJ, Zeng G, Yuen KY, Chen RC, Tang CL, Wang T, Chen PY, Xiang J, Li SY, Wang JL, Liang ZJ, Peng YX, Wei L, Liu Y, Hu YH, Peng P, Wang JM, Liu JY, Chen Z, Li G, Zheng ZJ, Qiu SQ, Luo J, Ye CJ, Zhu SY, Zhong NS, China Medical Treatment Expert Group for C. Clinical Characteristics of Coronavirus Disease 2019 in China. $N$ Engl J Med 2020; 382: 1708-1720.

2. Zhou P, Yang XL, Wang XG, Hu B, Zhang L, Zhang W, Si HR, Zhu Y, Li B, Huang CL, Chen HD, Chen J, Luo Y, Guo H, Jiang RD, Liu MQ, Chen Y, Shen XR, Wang X, Zheng XS, Zhao K, Chen QJ, Deng F, Liu LL, Yan B, Zhan FX, Wang YY, Xiao GF, Shi ZL. A pneumonia outbreak associated with a new coronavirus of probable bat origin. Nature 2020; 579: 270-273.

3. Johns Hopkins School of Medicine. Coronavirus resource center. 2020, April 3. Available from: https://coronavirus.jhu.edu/map.html.

4. Coronaviridae Study Group of the International Committee on Taxonomy of V. The species Severe acute respiratory syndrome-related coronavirus: classifying 2019-nCoV and naming it SARS-CoV-2. Nat Microbiol 2020; 5: 536-544.

5. Hoffmann M, Kleine-Weber H, Schroeder S, Kruger N, Herrler T, Erichsen S, Schiergens TS, Herrler G, Wu NH, Nitsche A, Muller MA, Drosten C, Pohlmann S. SARS-CoV2 Cell Entry Depends on ACE2 and TMPRSS2 and Is Blocked by a Clinically Proven Protease Inhibitor. Cell 2020; 181: 271-280 e278.

6. Wolfel R, Corman VM, Guggemos W, Seilmaier M, Zange S, Muller MA, Niemeyer D, Jones TC, Vollmar P, Rothe C, Hoelscher M, Bleicker T, Brunink S, Schneider J, Ehmann R, Zwirglmaier K, Drosten C, Wendtner C. Virological assessment of hospitalized patients with COVID-2019. Nature 2020; 581: 465-469.

7. Huang Q, Wu X, Zheng X, Luo S, Xu S, Weng J. Targeting inflammation and cytokine storm in COVID-19. Pharmacol Res 2020; 159: 105051.

8. Jose RJ, Manuel A. COVID-19 cytokine storm: the interplay between inflammation and coagulation. Lancet Respir Med 2020; 8: e46-e47.

9. Mehta P, McAuley DF, Brown M, Sanchez E, Tattersall RS, Manson JJ, Hlh Across Speciality Collaboration UK. COVID-19: consider cytokine storm syndromes and immunosuppression. Lancet 2020; 395: 1033-1034. 
10. Zhang X, Tan Y, Ling Y, Lu G, Liu F, Yi Z, Jia X, Wu M, Shi B, Xu S, Chen J, Wang W, Chen B, Jiang L, Yu S, Lu J, Wang J, Xu M, Yuan Z, Zhang Q, Zhang X, Zhao G, Wang S, Chen S, Lu H. Viral and host factors related to the clinical outcome of COVID19. Nature 2020; 583: 437-440.

11. Pedersen IM, Cheng G, Wieland S, Volinia S, Croce CM, Chisari FV, David M. Interferon modulation of cellular microRNAs as an antiviral mechanism. Nature 2007; 449: 919922.

12. Globinska A, Pawelczyk M, Kowalski ML. MicroRNAs and the immune response to respiratory virus infections. Expert Rev Clin Immunol 2014; 10: 963-971.

13. O'Neill LA, Sheedy FJ, McCoy CE. MicroRNAs: the fine-tuners of Toll-like receptor signalling. Nat Rev Immunol 2011; 11: 163-175.

14. Jia S, Zhai H, Zhao M. MicroRNAs regulate immune system via multiple targets. Discov Med 2014; 18: 237-247.

15. Krek A, Grun D, Poy MN, Wolf R, Rosenberg L, Epstein EJ, MacMenamin P, da Piedade I, Gunsalus KC, Stoffel M, Rajewsky N. Combinatorial microRNA target predictions. Nat Genet 2005; 37: 495-500.

16. John B, Sander C, Marks DS. Prediction of human microRNA targets. Methods Mol Biol 2006; 342: 101-113.

17. Poy MN, Eliasson L, Krutzfeldt J, Kuwajima S, Ma X, Macdonald PE, Pfeffer S, Tuschl T, Rajewsky N, Rorsman P, Stoffel M. A pancreatic islet-specific microRNA regulates insulin secretion. Nature 2004; 432: 226-230.

18. Iorio MV, Ferracin M, Liu CG, Veronese A, Spizzo R, Sabbioni S, Magri E, Pedriali M, Fabbri M, Campiglio M, Menard S, Palazzo JP, Rosenberg A, Musiani P, Volinia S, Nenci I, Calin GA, Querzoli P, Negrini M, Croce CM. MicroRNA gene expression deregulation in human breast cancer. Cancer Res 2005; 65: 7065-7070.

19. Jovanovic M, Hengartner MO. miRNAs and apoptosis: RNAs to die for. Oncogene 2006; 25: 6176-6187.

20. Blenkiron C, Miska EA. miRNAs in cancer: approaches, aetiology, diagnostics and therapy. Hum Mol Genet 2007; 16 Spec No 1: R106-113.

21. Poy MN, Spranger M, Stoffel M. microRNAs and the regulation of glucose and lipid metabolism. Diabetes Obes Metab 2007; 9 Suppl 2: 67-73.

22. van Rooij E, Olson EN. MicroRNAs: powerful new regulators of heart disease and provocative therapeutic targets. J Clin Invest 2007; 117: 2369-2376. 
23. Mallick B, Ghosh Z, Chakrabarti J. MicroRNome analysis unravels the molecular basis of SARS infection in bronchoalveolar stem cells. PLoS One 2009; 4: e7837.

24. Lai FW, Stephenson KB, Mahony J, Lichty BD. Human coronavirus OC43 nucleocapsid protein binds microRNA 9 and potentiates NF-kappaB activation. $J$ Virol 2014; 88: 5465.

25. Boldin MP, Taganov KD, Rao DS, Yang L, Zhao JL, Kalwani M, Garcia-Flores Y, Luong M, Devrekanli A, Xu J, Sun G, Tay J, Linsley PS, Baltimore D. miR-146a is a significant brake on autoimmunity, myeloproliferation, and cancer in mice. $J$ Exp Med 2011; 208: 1189-1201.

26. Krutzfeldt J, Rajewsky N, Braich R, Rajeev KG, Tuschl T, Manoharan M, Stoffel M. Silencing of microRNAs in vivo with 'antagomirs'. Nature 2005; 438: 685-689.

27. Bonci D, Coppola V, Musumeci M, Addario A, Giuffrida R, Memeo L, D'Urso L, Pagliuca A, Biffoni M, Labbaye C, Bartucci M, Muto G, Peschle C, De Maria R. The miR-15amiR-16-1 cluster controls prostate cancer by targeting multiple oncogenic activities. Nat Med 2008; 14: 1271-1277.

28. Couzin J. MicroRNAs make big impression in disease after disease. Science 2008; 319: 1782-1784.

29. Fontana L, Fiori ME, Albini S, Cifaldi L, Giovinazzi S, Forloni M, Boldrini R, Donfrancesco A, Federici V, Giacomini P, Peschle C, Fruci D. Antagomir-17-5p abolishes the growth of therapy-resistant neuroblastoma through p21 and BIM. PLoS ONE 2008; 3: e2236.

30. Vigorito E, Kohlhaas S, Lu D, Leyland R. miR-155: an ancient regulator of the immune system. Immunol Rev 2013; 253: 146-157.

31. Seddiki N, Brezar V, Ruffin N, Levy Y, Swaminathan S. Role of miR-155 in the regulation of lymphocyte immune function and disease. Immunology 2014; 142: 32-38.

32. Lu LF, Gasteiger G, Yu IS, Chaudhry A, Hsin JP, Lu Y, Bos PD, Lin LL, Zawislak CL, Cho S, Sun JC, Leslie CS, Lin SW, Rudensky AY. A Single miRNA-mRNA Interaction Affects the Immune Response in a Context- and Cell-Type-Specific Manner. Immunity 2015; 43: 52-64.

33. Hsin JP, Lu Y, Loeb GB, Leslie CS, Rudensky AY. The effect of cellular context on miR155-mediated gene regulation in four major immune cell types. Nat Immunol 2018; 19: 1137-1145. 
34. O'Connell RM, Taganov KD, Boldin MP, Cheng G, Baltimore D. MicroRNA-155 is induced during the macrophage inflammatory response. Proc Natl Acad Sci U S A 2007; 104: 1604-1609.

35. Gracias DT, Stelekati E, Hope JL, Boesteanu AC, Doering TA, Norton J, Mueller YM, Fraietta JA, Wherry EJ, Turner M, Katsikis PD. The microRNA miR-155 controls CD8(+) T cell responses by regulating interferon signaling. Nat Immunol 2013; 14 : 593-602.

36. Tsai CY, Allie SR, Zhang W, Usherwood EJ. MicroRNA miR-155 affects antiviral effector and effector Memory CD8 T cell differentiation. J Virol 2013; 87: 2348-2351.

37. Bhela S, Mulik S, Reddy PB, Richardson RL, Gimenez F, Rajasagi NK, Veiga-Parga T, Osmand AP, Rouse BT. Critical role of microRNA-155 in herpes simplex encephalitis. J Immunol 2014; 192: 2734-2743.

38. Jiang M, Broering R, Trippler M, Wu J, Zhang E, Zhang X, Gerken G, Lu M, Schlaak JF. MicroRNA-155 controls Toll-like receptor 3- and hepatitis $\mathrm{C}$ virus-induced immune responses in the liver. J Viral Hepat 2014; 21: 99-110.

39. Goncalves-Alves E, Saferding V, Schliehe C, Benson R, Kurowska-Stolarska M, Brunner JS, Puchner A, Podesser BK, Smolen JS, Redlich K, Bonelli M, Brewer J, Bergthaler A, Steiner G, Bluml S. MicroRNA-155 Controls T Helper Cell Activation During Viral Infection. Front Immunol 2019; 10: 1367.

40. Wu Z, Hao R, Li P, Zhang X, Liu N, Qiu S, Wang L, Wang Y, Xue W, Liu K, Yang G, Cui J, Zhang C, Song H. MicroRNA expression profile of mouse lung infected with 2009 pandemic H1N1 influenza virus. PLoS One 2013; 8: e74190.

41. Choi EJ, Kim HB, Baek YH, Kim EH, Pascua PN, Park SJ, Kwon HI, Lim GJ, Kim S, Kim YI, Choi YK. Differential microRNA expression following infection with a mouseadapted, highly virulent avian H5N2 virus. BMC Microbiol 2014; 14: 252.

42. Pociask DA, Robinson KM, Chen K, McHugh KJ, Clay ME, Huang GT, Benos PV, Janssen-Heininger YMW, Kolls JK, Anathy V, Alcorn JF. Epigenetic and Transcriptomic Regulation of Lung Repair during Recovery from Influenza Infection. Am J Pathol 2017; 187: 851-863.

43. Woods PS, Doolittle LM, Rosas LE, Nana-Sinkam SP, Tili E, Davis IC. Increased expression of microRNA-155-5p by alveolar type II cells contributes to development of lethal ARDS in H1N1 influenza A virus-infected mice. Virology 2020; 545: 40-52. 44. De Smet EG, Van Eeckhoutte HP, Avila Cobos F, Blomme E, Verhamme FM, Provoost S, Verleden SE, Venken K, Maes T, Joos GF, Mestdagh P, Brusselle GG, Bracke KR. The 
role of miR-155 in cigarette smoke-induced pulmonary inflammation and COPD. Mucosal Immunol 2020; 13: 423-436.

45. Tay MZ, Poh CM, Renia L, MacAry PA, Ng LFP. The trinity of COVID-19: immunity, inflammation and intervention. Nat Rev Immunol 2020; 20: 363-374.

46. Huang C, Wang Y, Li X, Ren L, Zhao J, Hu Y, Zhang L, Fan G, Xu J, Gu X, Cheng Z, Yu T, Xia J, Wei Y, Wu W, Xie X, Yin W, Li H, Liu M, Xiao Y, Gao H, Guo L, Xie J, Wang G, Jiang R, Gao Z, Jin Q, Wang J, Cao B. Clinical features of patients infected with 2019 novel coronavirus in Wuhan, China. Lancet 2020; 395: 497-506.

47. Thai TH, Calado DP, Casola S, Ansel KM, Xiao C, Xue Y, Murphy A, Frendewey D, Valenzuela D, Kutok JL, Schmidt-Supprian M, Rajewsky N, Yancopoulos G, Rao A, Rajewsky K. Regulation of the germinal center response by microRNA-155. Science 2007; 316: 604-608.

48. Zhou H, Huang X, Cui H, Luo X, Tang Y, Chen S, Wu L, Shen N. miR-155 and its starform partner miR-155* cooperatively regulate type I interferon production by human plasmacytoid dendritic cells. Blood 2010; 116: 5885-5894.

49. Gottwein E. Roles of microRNAs in the life cycles of mammalian viruses. Curr Top Microbiol Immunol 2013; 371: 201-227.

50. Zeng FR, Tang LJ, He Y, Garcia RC. An update on the role of miRNA-155 in pathogenic microbial infections. Microbes Infect 2015; 17: 613-621.

51. Mehta A, Baltimore D. MicroRNAs as regulatory elements in immune system logic. Nat Rev Immunol 2016; 16: 279-294.

52. Dickey LL, Hanley TM, Huffaker TB, Ramstead AG, O'Connell RM, Lane TE. MicroRNA 155 and viral-induced neuroinflammation. J Neuroimmunol 2017; 308: 17-24.

53. Badry A, Jaspers VLB, Waugh CA. Environmental pollutants modulate RNA and DNA virus-activated miRNA-155 expression and innate immune system responses: Insights into new immunomodulative mechanisms. J Immunotoxicol 2020; 17: 86-93.

54. Emanuel W, Kirstin M, Vedran F, Asija D, Theresa GL, Roberto A, Filippos K, David K, Salah A, Christopher B, Anja R, Ivano L, Andranik I, Tommaso M, Simone DG, Patrick PJ, Alexander MM, Daniela N, Matthias S, Altuna A, Nikolaus R, Christian D, Markus L. Bulk and single-cell gene expression profiling of SARS-CoV-2 infected human cell lines identifies molecular targets for therapeutic intervention. 2020: 2020.2005.2005.079194.

55. Chow JT, Salmena L. Prediction and Analysis of SARS-CoV-2-Targeting MicroRNA in Human Lung Epithelium. Genes (Basel) 2020; 11. 
56. Lutz C, Maher L, Lee C, Kang W. COVID-19 preclinical models: human angiotensinconverting enzyme 2 transgenic mice. Hum Genomics 2020; 14: 20.

57. Golden JW, Cline CR, Zeng X, Garrison AR, Carey BD, Mucker EM, White LE, Shamblin JD, Brocato RL, Liu J, Babka AM, Rauch HB, Smith JM, Hollidge BS, Fitzpatrick C, Badger CV, Hooper JW. Human angiotensin-converting enzyme 2 transgenic mice infected with SARS-CoV-2 develop severe and fatal respiratory disease. JCI Insight $2020 ; 5$.

58. Winkler ES, Bailey AL, Kafai NM, Nair S, McCune BT, Yu J, Fox JM, Chen RE, Earnest JT, Keeler SP, Ritter JH, Kang LI, Dort S, Robichaud A, Head R, Holtzman MJ, Diamond MS. SARS-CoV-2 infection of human ACE2-transgenic mice causes severe lung inflammation and impaired function. Nat Immunol 2020; 21: 1327-1335.

59. Jiang RD, Liu MQ, Chen Y, Shan C, Zhou YW, Shen XR, Li Q, Zhang L, Zhu Y, Si HR, Wang Q, Min J, Wang X, Zhang W, Li B, Zhang HJ, Baric RS, Zhou P, Yang XL, Shi ZL. Pathogenesis of SARS-CoV-2 in Transgenic Mice Expressing Human Angiotensin-Converting Enzyme 2. Cell 2020; 182: 50-58 e58.

60. Del Valle DM, Kim-Schulze S, Huang HH, Beckmann ND, Nirenberg S, Wang B, Lavin Y, Swartz TH, Madduri D, Stock A, Marron TU, Xie H, Patel M, Tuballes K, Van Oekelen O, Rahman A, Kovatch P, Aberg JA, Schadt E, Jagannath S, Mazumdar M, Charney AW, Firpo-Betancourt A, Mendu DR, Jhang J, Reich D, Sigel K, CordonCardo C, Feldmann M, Parekh S, Merad M, Gnjatic S. An inflammatory cytokine signature predicts COVID-19 severity and survival. Nat Med 2020; 26: 1636-1643.

61. Heimfarth L, Serafini MR, Martins-Filho PR, Quintans JSS, Quintans-Junior LJ. Drug repurposing and cytokine management in response to COVID-19: A review. Int Immunopharmacol 2020; 88: 106947.

62. Ragab D, Salah Eldin H, Taeimah M, Khattab R, Salem R. The COVID-19 Cytokine Storm; What We Know So Far. Front Immunol 2020; 11: 1446.

63. Tang Y, Liu J, Zhang D, Xu Z, Ji J, Wen C. Cytokine Storm in COVID-19: The Current Evidence and Treatment Strategies. Front Immunol 2020; 11: 1708. 


\section{FIGURE LEGENDS}

Fig. 1. SARS-CoV-2 viral load in COVID-19 patients. The RNA from nasopharyngeal swabs of human subjects $(n=99)$ tested for SARS-CoV-2 infection were analyzed for the expression of SARS-CoV-2 genes, ORF1ab, $\mathrm{N}$ and $\mathrm{S}$, by qPCR. The plots depict mean $\mathrm{Ct}$ values of the 3 indicated genes analyzed in SARS-CoV-2 positive patients: (A) all patients $(n=59)$ and $(\mathbf{B})$ male $(n=21)$ versus female patients $(n=38)$. The error bars represent \pm SEM.

Fig. 2. Expression of miR-155 in SARS-CoV-2 positive patients. The expression of miR155 in (A) individual SARS-CoV-2 positive patients and (B) average levels in SARS-CoV-2 positive patients with $\geq 2$ fold upregulation $(n=20)$ compared to $S A R S-C o V-2$ negative $(n=40)$ was analyzed by Taqman assay. (C) The relative miR-155 levels in male patients (positive $\mathrm{n}=21$ versus negative $\mathrm{n}=18$ for $\mathrm{SARS}=\mathrm{CoV}-2$ ) and female patients (positive $\mathrm{n}=38$ versus negative $\mathrm{n}=22$ for $\mathrm{SARS}=\mathrm{CoV}-2$ ) are depicted.

Fig. 3. Impact of anti-miR-155 treatment on tg-mice hACE2 infected with SARS-CoV-2. Tg-mice hACE2 was infected by intranasal injection with SARS-CoV-2 at $2.8 \times 10^{3} \mathrm{pfu}$, were treated with anti-miR-155 ( $\mathrm{n}=6)$ or anti-miR-control (Ctrl, scrambled, $n=3)$ at a dose of 25 $\mathrm{mg} / \mathrm{kg}$ mice body weight administered on 0 - and 4-day post-infection via retro-orbital injection. (A) Expression level of miR-155 in lung tissues of anti-miR-155-treated tg-mice $(n=6)$ compared to control tg-mice $(n=3)$ was measured. (B) Kaplan-Meier survival curve depicts the differential survival of anti-miR-155-treated compared to control tg-mice. (C) Percent body weight change in the two groups of animals is shown.

Fig. 4. Impact of anti-miR-155 treatment on pro-inflammatory cytokines. The BAL fluid obtained from SARS-CoV-2-infected tg-mice hACE2 treated with anti-miR-155 ( $\mathrm{n}=5)$, and tg-mice treated similarly with anti-miR-control (Ctrl, scrambled, $\mathrm{n}=1)$ was analyzed for 
cytokine profile by Luminex. Relative levels of the cytokines, G-CSF, IL-1 $\alpha$, IL-9, IL-12 (p70), KC, LIX, MIP-2, and VEGF, significantly altered are shown.

Fig. 5. Impact of anti-miR-155 treatment on anti-inflammatory and anti-viral cytokines. The cytokine profile of the BAL fluid obtained from SARS-CoV-2-infected tg-mice hACE2 treated with anti-miR-155 ( $\mathrm{n}=5)$ or with anti-miR-control (Ctrl, scrambled, $\mathrm{n}=1)$ was analyzed by Luminex. Relative levels of the cytokines, eotaxin, IFN- $\gamma$, IP-10, MCP-1, M-CSF, MIG, MIP-1 $\alpha$, MIP-1 $\beta$, and TNF- $\alpha$, that are significantly altered are shown. 

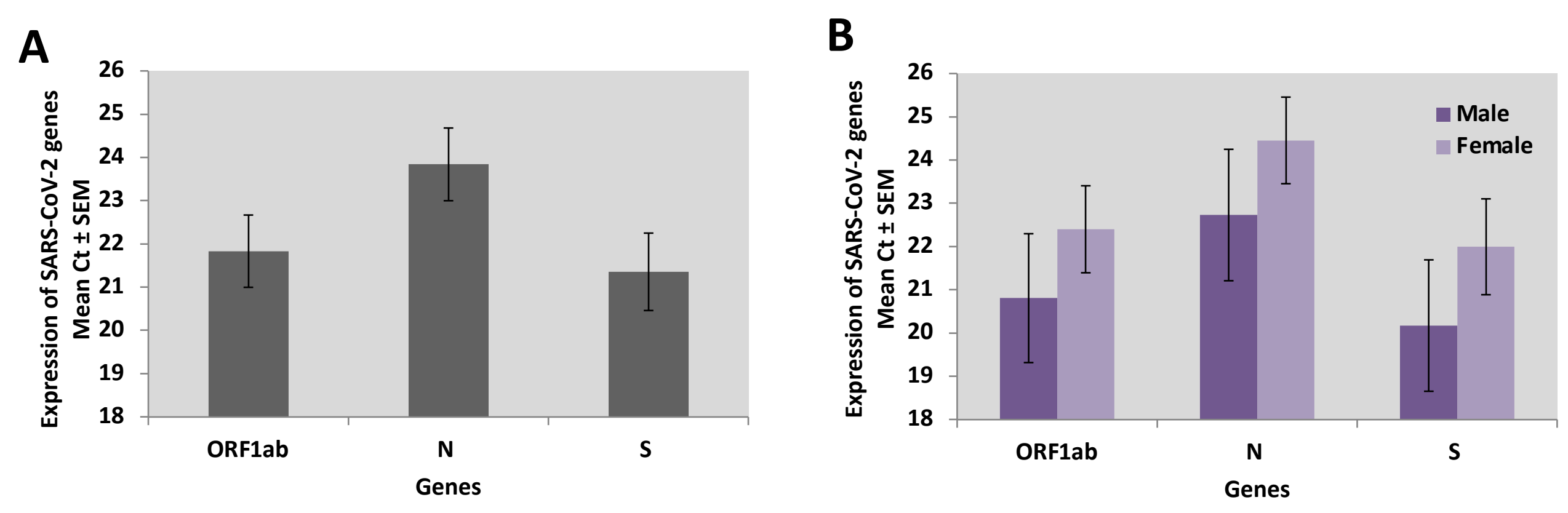
A

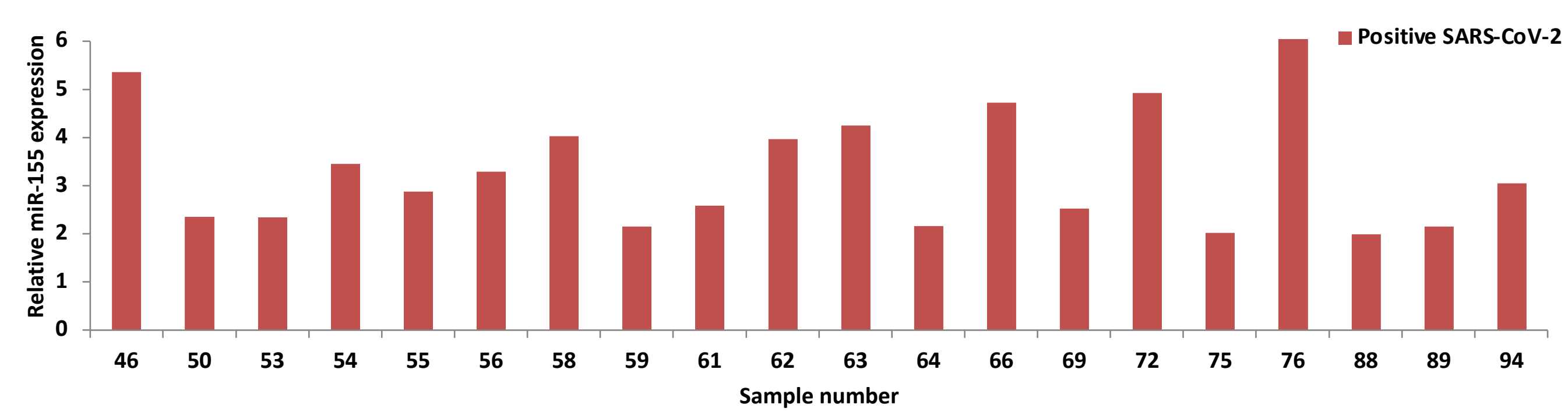

B

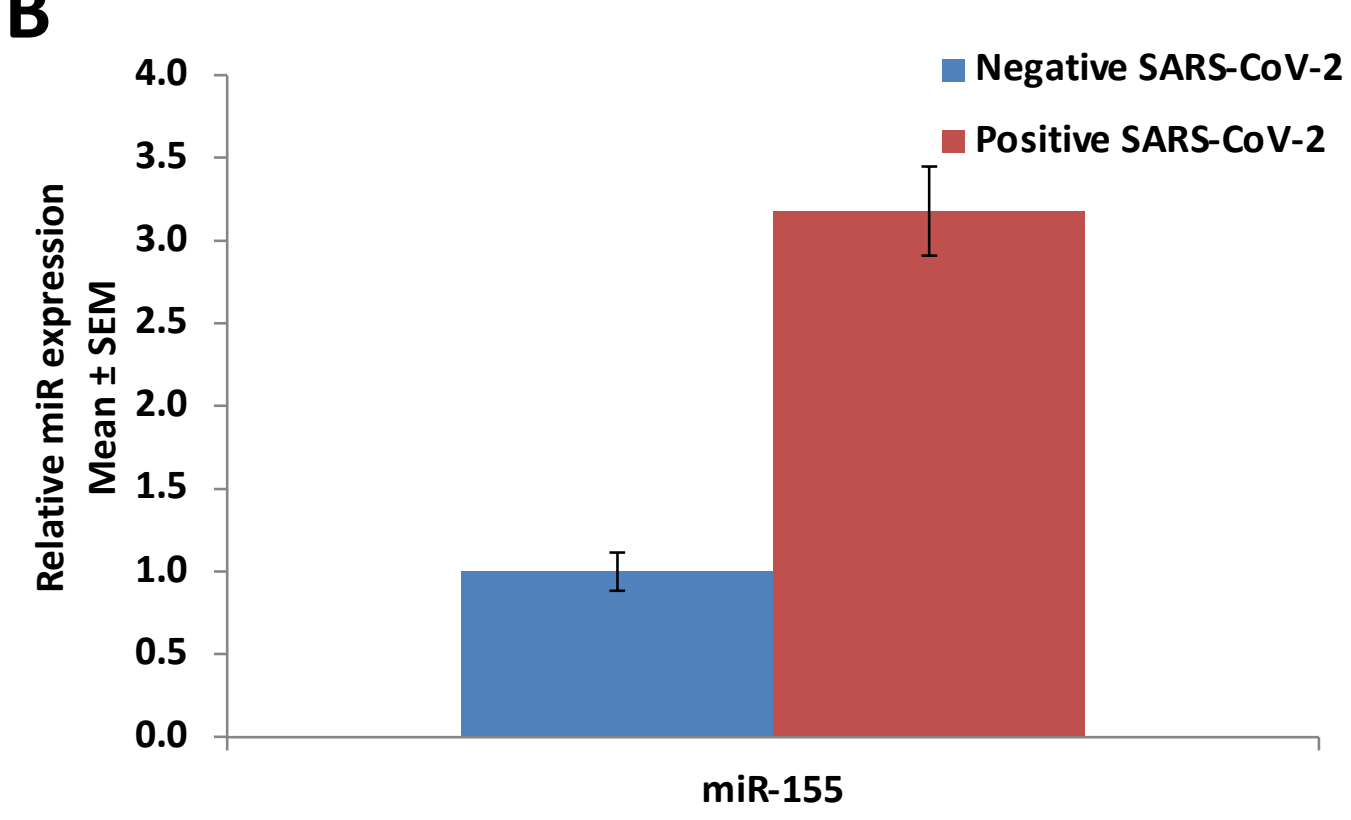

C
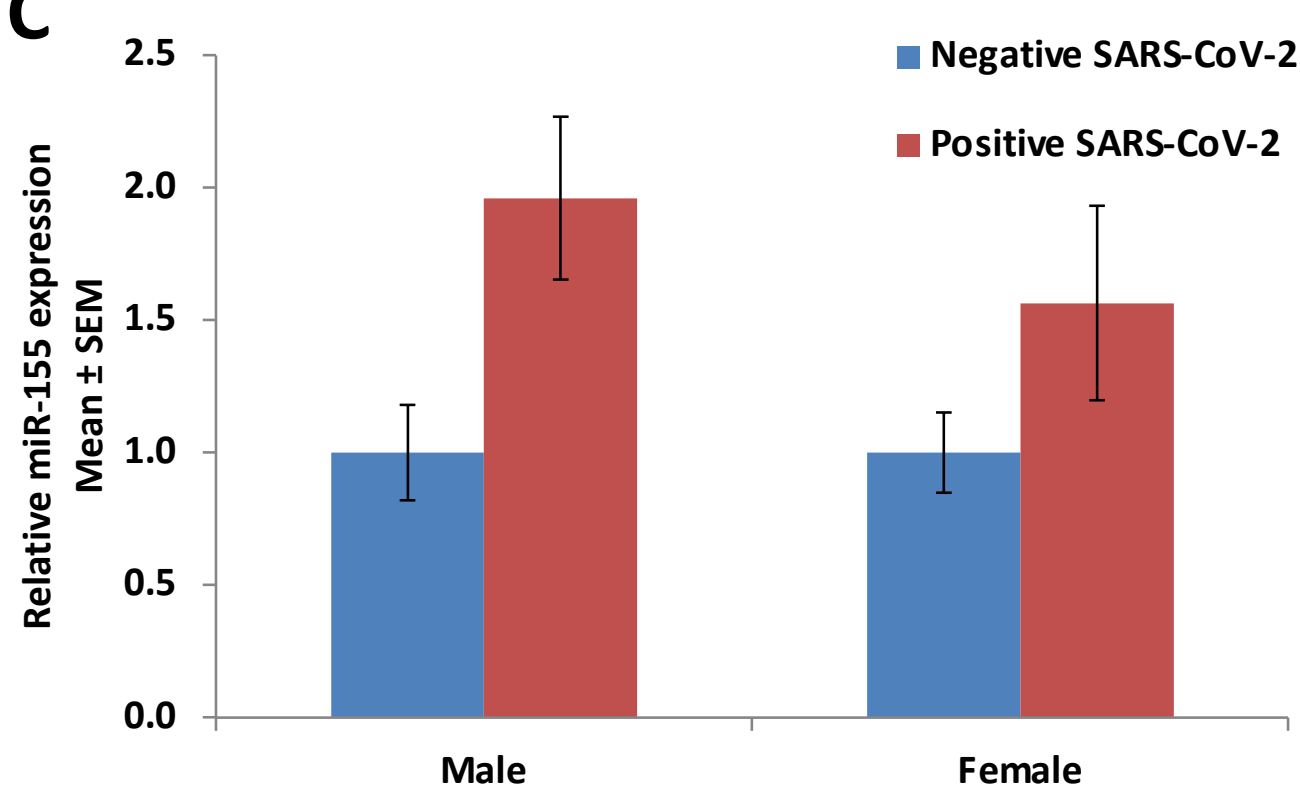


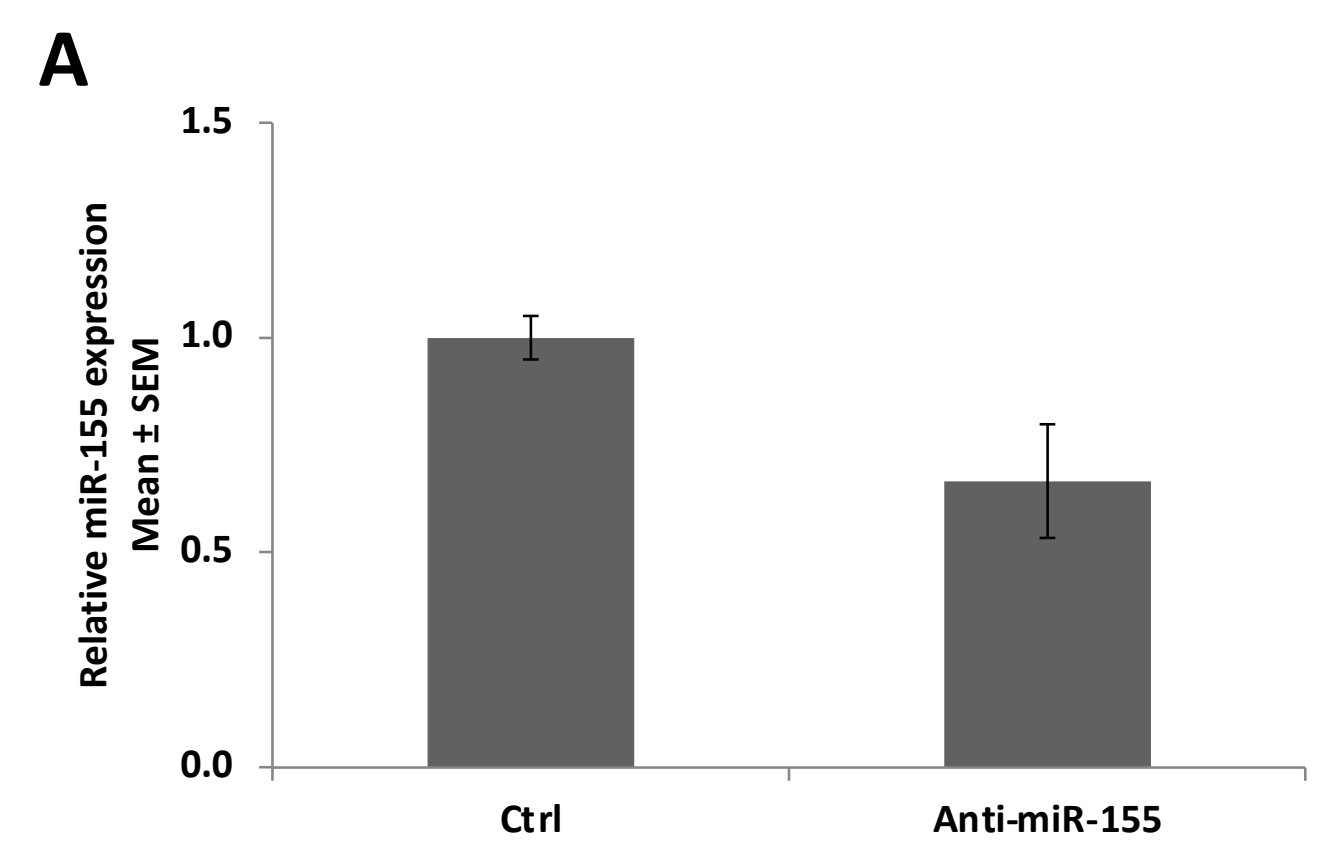

B

Survival proportions: Survival of Survival

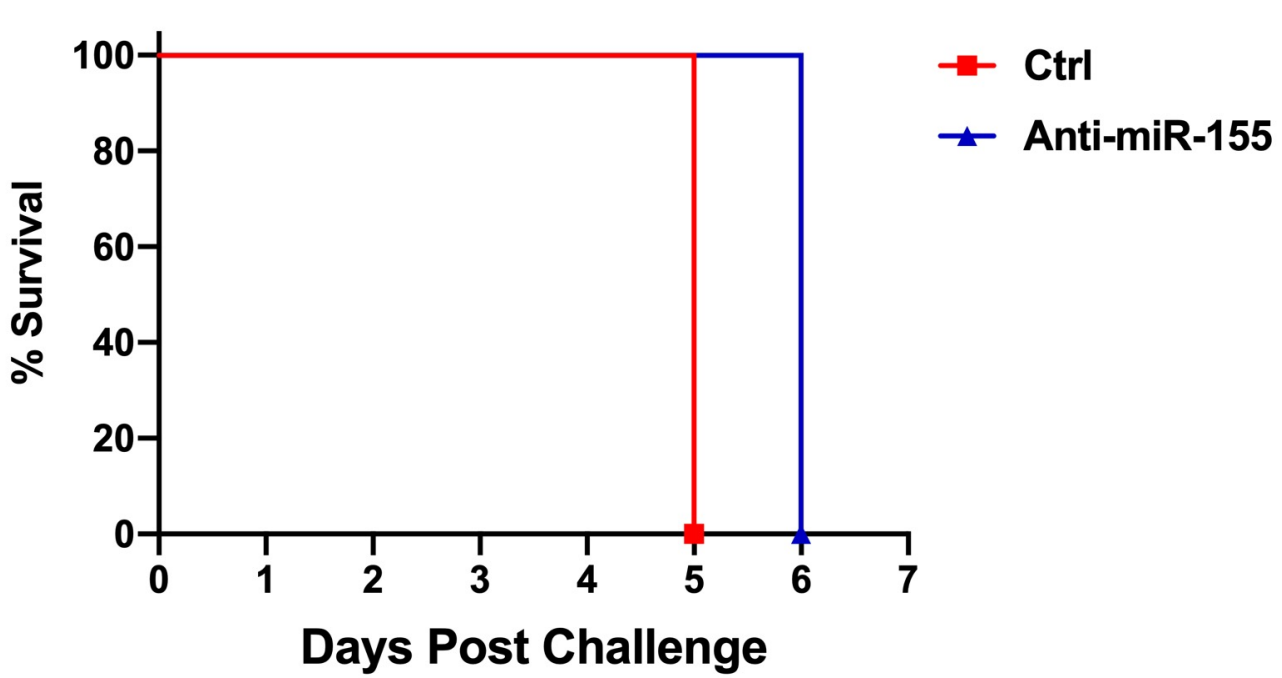

C

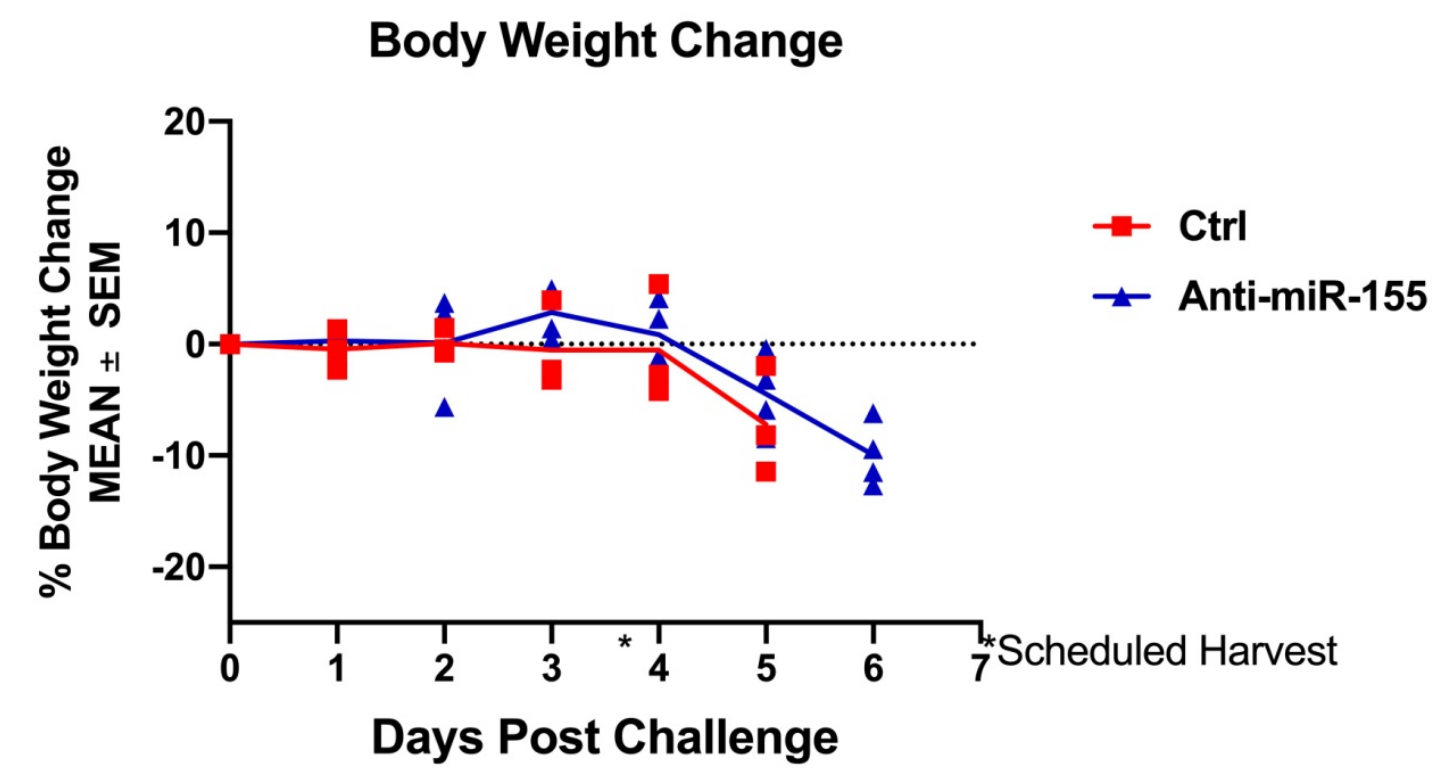



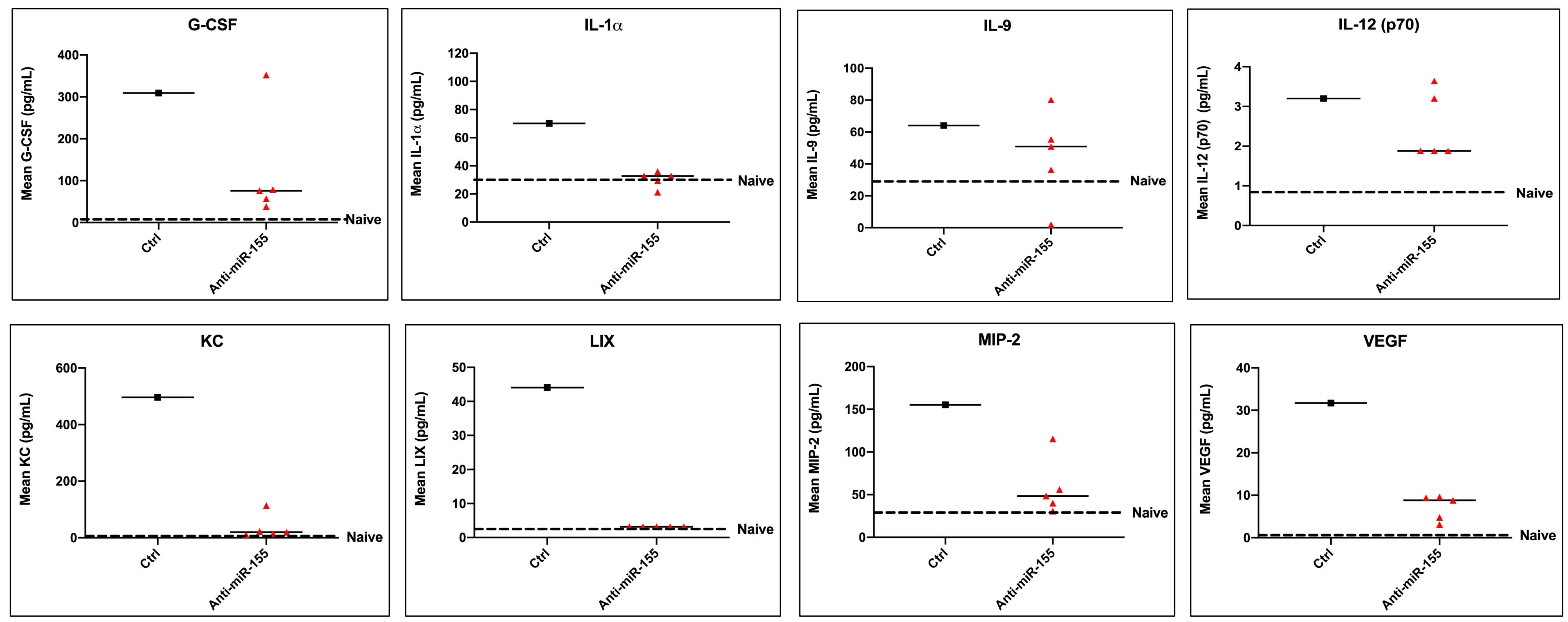

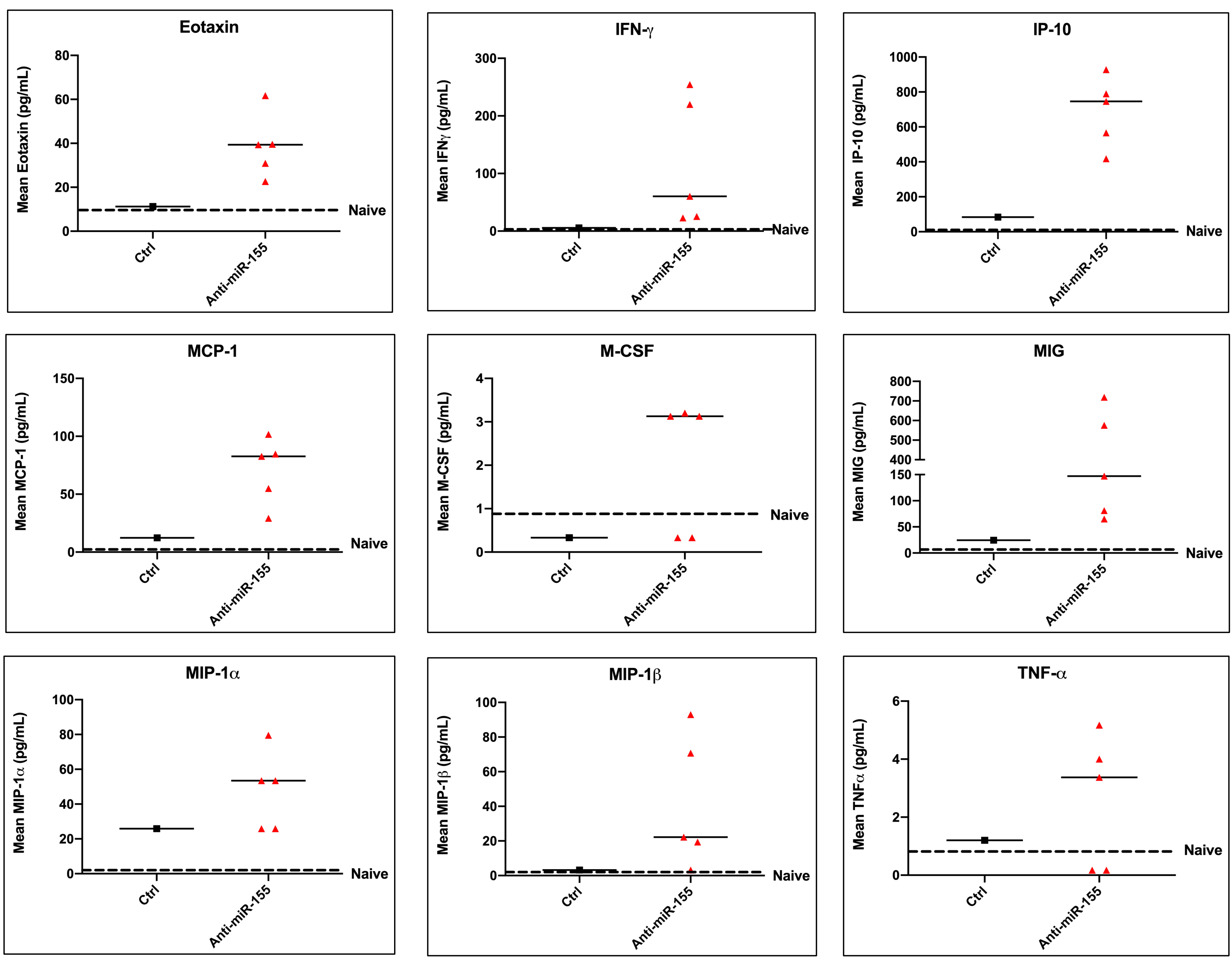